\title{
Lack of association between haemostatic variables and the presence or the extent of coronary atherosclerosis
}

\author{
ULRICH SCHMITZ-HUEBNER, SIMON G THOMPSON, * LEOPOLD BALLEISEN, \\ CHRISTIAN FECHTRUP, WOLFGANG GROSSE-HEITMEYER, \\ BRUNO KIRCHHOF, ECKEHARD MOST, ULF-STEFFEN MÜLLER, \\ CHRISTIANE SEIFFERT, DIETMAR SEIFFERT, JÜRGEN VAN DE LOO
}

From the Department of Internal Medicine and the Institute of Arteriosclerosis Research, University of Münster, Federal Republic of Germany; and the ${ }^{\star}$ Department of Environmental and Preventive Medicine, St Bartholomew's Hospital Medical College, University of London, London

SUMMARY Blood samples were taken for haemostatic analysis from 225 patients with angina pectoris who were admitted to hospital for coronary angiography. $\beta$ thromboglobulin, platelet factor 3, platelet factor 4, factor VII:C, factor VIII:C, von Willebrand factor antigen, activated partial thromboplastin time, fibrinogen, antithrombin III, protein C:Ag, plasminogen, and antiplasmin were measured before angiography. Patients who had had a myocardial infarction in the two months before the investigation were excluded from the study. Multiple linear regression analysis showed that none of the haemostatic variables contributed independently to the prediction of an angiographic score that indicated the extent of coronary atherosclerosis. History of myocardial infarction, male sex, worsening of angina pectoris, serum triglycerides, and ejection fraction were independently associated with the angiographic score. There were some significant correlations between haemostatic variables and conventional risk factors for coronary heart disease.

Thus data obtained from haemostatic analyses of peripheral venous blood do not permit the presence or the extent of atherosclerosis in coronary arteries to be predicted.

There is increasing evidence that coronary heart disease is associated with an activation of the clotting system. Coronary thrombosis occurs in most patients with acute myocardial infarction, ${ }^{12}$ and there is also epidemiological evidence indicating the pathogenetic importance of haemostatic function in coronary heart disease. ${ }^{3}$ The precise role of haemostatic factors in the presence of coronary atherosclerosis, however, is still unknown.

Although recent clinical data support the proposition that activation of the coagulation and the platelet system is closely associated with myocardial ischaemia, ${ }^{45}$ there is little information on the relation between the development of coronary atherosclerosis and the haemostatic system. Nichols et al did not

Requests for reprints to Professor Ulrich Schmitz-Huebner, Department of Internal Medicine, University of Münster, D-4400 Münster, Federal Republic of Germany.

Accepted for publication 15 October 1987 detect increased concentrations of platelet factor 4, $\beta$ thromboglobulin, and fibrinopeptide $A$ in a group of patients with abnormal coronary angiograms without previous myocardial infarction. ${ }^{6}$

We have measured several haemostatic variables in blood samples from 225 patients with angina pectoris. All of them also had coronary angiography within the next two days. We graded the extent of coronary atherosclerosis according to an angiographic score and studied the associations of this score with different clinical variables as well as the haemostatic tests. Thus the aim of this study was to find out, in a cross sectional survey, whether there was a relation between stenotic disease and clotting activity.

\section{Patients and methods}

PATIENTS

We studied men and women of all ages with angina 
288

who were admitted to hospital for coronary angiography. We excluded patients with non-cardiac diseases likely to cause death within one year, right heart failure with peripheral oedema, valve defects, or acute myocardial infarction within the preceding two months. Angina was described as "worsening" if the patient said that the attacks of chest pain had increased in frequency or in severity within recent weeks. Blood was drawn in the morning from patients at rest who had fasted and not smoked for at least eight hours. A record was kept of any drugs, particularly anticoagulants and platelet inhibitors, taken within 10 days before blood sampling.

\section{CORONARY ANGIOGRAPHY}

Left ventricular catheterisation and coronary angiography were performed percutaneously from the femoral artery according to the Judkins' technique. ${ }^{7}$ Coronary atherosclerosis on the arteriograms was scored from 1 to 5 as (1) no changes, (2) less than $50 \%$ stenosis (diameter reduction) in one or more vessels, (3) at least $50 \%$ stenosis in one vessel, (4) at least $50 \%$ stenosis in two vessels, and (5) at least $50 \%$ stenosis in three vessels. The ejection fraction was estimated according to Dodge $e t \mathrm{al}^{8}$ as modified by Kennedy et al. ${ }^{9}$ Akinesia and dyskinesia were defined according to Herman et al. ${ }^{10}$

\section{BLOOD SAMPLES}

Samples were drawn by venepuncture with a 19 gauge butterfly system by specially trained staff. The first $5 \mathrm{ml}$ was not used for haemostatic analyses. Blood for analysis was collected into precooled tubes containing Thrombotect. (Abbott, North Chicago, USA) reagent $(9+1 \mathrm{v} / \mathrm{v})$. These blood samples were used for the assays of platelet factor 4 and $\beta$ thromboglobulin. Blood samples were centrifuged at $0^{\circ} \mathrm{C}$ for $60 \mathrm{~min}$ at $1900 \mathrm{~g}$. Plasma was quick frozen and kept at $-70^{\circ} \mathrm{C}$ until assay. Blood for coagulation assays was mixed $(9+1 \mathrm{v} / \mathrm{v})$ with tri-sodium citrate solution $(0 \cdot 130 \mathrm{~mol} / 1, \mathrm{pH} 7 \cdot 5)$. Blood was centrifuged for $30 \mathrm{~min}$ at $2500 \mathrm{~g}\left(20^{\circ} \mathrm{C}\right)$ within 60 minutes of venepuncture. Plasma was snap frozen and kept at $-70^{\circ} \mathrm{C}$ before analysis. Samples that were used for assays of activated partial thromboplastin time and platelet factor 3 were not frozen and were used immediately.

\section{HAEMOSTATIC ASSAYS}

Platelet factor 4 in plasma was measured by the radioimmunoassay kit produced by Abbott and $\beta$ thromboglobulin by a radioimmunoassay kit supplied by Amersham (Buchler, Braunschweig, West Germany).

Factor VII:C and factor VIII:C were measured by a one-step assays with reagents and factor VIIdeficient plasma from Behringwerke AG (Marburg,
Schmitz-Huebner, Thompson, Balleisen, et al $\stackrel{\frac{m}{I}}{\stackrel{T}{\Phi}}$ West Germany). Standard human plasma (Behring- $\stackrel{\stackrel{\Xi}{c}}{c}$ werke) and a plasma pool prepared from 25 male donors (aged 20-40 years) were used as a reference $\stackrel{5}{9}$ plasma for the standard curves for factor VII:C and $\bar{O}$ factor VIII:C respectively. Results were expressed as 흘 percentages of the standards. Fibrinogen was $\frac{\bar{c}}{2}$ measured according to the method of Clauss, ${ }^{11}$ with $\stackrel{\varnothing}{\varnothing}$ instructions and reagents from Behringwerke. Platelet factor 3 was measured in freshly prepared platelet rich plasma by a microcoagulation assay described in detail elsewhere. ${ }^{12}$

Activated partial thromboplastin time was $\stackrel{\omega}{\circ}$ measured semiautomatically with a coagulometer (Amelung, Lemgo, West Germany) and a cephalin of reagent provided by the National (UK) Reference $\dot{\omega}$ Laboratory for Anticoagulant Reagents and Control, $\underset{\infty}{\sim}$ Manchester. The biological activities of the protease inhibitors antithrombin III and antiplasmin were $\frac{\text { I }}{I}$ measured with the synthetic substrates $S 2238^{13}$ and $\vec{r}$ S2251, ${ }^{14}$ respectively, supplied by KabiVitrum (Munich, West Germany). Plasminogen was measured by means of the synthetic substrate $S 2251^{15}$ supplied by Kabi. von Willebrand factor antigen was $\rightleftharpoons$ measured by the electroimmunoassay described by Laurell. ${ }^{16}$ Heterologous antiserum against human von Willebrand factor: $\mathrm{Ag}$ (Behringwerke) was used. The results were expressed as a percentage of the standard prepared from normal human blood donors $\stackrel{\circ}{\circ}$ as described above. Protein $C$ antigen was assayed $\stackrel{\unrhd}{\unrhd}$ by an enzyme linked immunoadsorbent assay kit $^{17} \overrightarrow{\overrightarrow{0}}$ (Boehringer Mannheim, Mannheim, West Ger- $\frac{3}{3}$ many).

STATISTICAL ANALYSIS

Multiple linear regression with forward stepwise selection of variables with a critical $p$ value for entry of 0.05 was applied to test for possible relations between the angiographic score and the other variables. Logarithmic transformation of some variables was used to achieve an approximately normal distri- 0 bution. $p$ values, given to the nearest significant number if $<0.0001$, were derived from the multiple $\frac{}{0}$ regressions. Independent associations with each of the individual haemostatic variables were also or investigated by multiple regression analyses. In $\mathrm{O}$ analyses of activated partial thromboplastin time, factor VII:C, or protein C:Ag we excluded the 40 O patients on anticoagulant treatment. Because the number of comparisons was large results of only borderline statistical significance may have arisen by $\stackrel{?}{+}$ chance.

\section{Results}

CHARACTERISTICS OF THE PATIENTS ADMITTED

TO THE STUDY
Two hundred and sixty three patients were admitted 
to the study. Thirty eight were excluded because angiograms or other relevant documents were lost ( $n=12)$, blood sampling was inadequate $(n=14)$, or incompatibilities with the entry criteria were detected after entry to the trial $(n=12)$.

Table 1 summarises the main clinical data of the 225 patients. Ninety nine patients of this group described themselves as ex-smokers and 42 were active smokers. The men were $52.4(7 \cdot 1)$ years old, and the women $52.9(6 \cdot 6)$ (mean (SD)).

\section{INDEPENDENT ASSOCIATIONS WITH THE}

\section{ANGIOGRAPHIC SCORE}

Regression analysis showed that the following were independently associated with increases of the angiographic score: history of myocardial infarction $(\mathrm{p}<0.0001$, table 1$)$, male sex $(\mathrm{p}<0.0001$, table 1$)$, worsening of angina pectoris $(p<0.0001$, table 1$)$, increased serum triglyceride concentration $(p=$ 0.003 , table 2$)$, and lower ejection fraction $(p=0.02$, table 2). Although white blood cell count (table 2), current or past smoking (table 1), and the presence of akinesia or dyskinesia (table 1) were positively related to the angiographic score, these associations did not remain statistically significant when the above variables had been taken into account. The same applies to serum cholesterol concentrations (table 2), which were positively correlated with serum triglycerides $(r=0.36)$. Among those with a past history of myocardial infarction, there was no significant association between the interval since this event and the angiographic score. None of the haematological or haemostatic variables (table 2) contributed independently to the prediction of this score. In addition, no significant differences were seen when the haemostatic variables measured in the patients without angiographic changes were compared with the corresponding values in the patients with coronary atherosclerosis.
INDEPENDENT ASSOCIATIONS WITH

HAEMOSTATIC VARIABLES

There were several significant independent associations between haemostatic variables and relevant clinical or laboratory variables. Patients with a history of myocardial infarction had a higher average von Willebrand factor:Ag than those without $(123 \%$ vs $102 \%$, table $2, \mathrm{p}=0.003$ ). The ejection fraction was associated with concentrations of antiplasmin $(r=0.18, p=0.009)$ and inversely correlated with concentrations of $\beta$ thromboglobulin ( $r=-0 \cdot 15$, $p=0.03)$ and fibrinogen $(r=-0.18, p=0.006)$. Triglyceride concentrations correlated with plasminogen ( $r=0.21, p=0.003$ ) and factor VII:C $(r=0.40, p=<0.0001)$. Increases in cholesterol concentration were associated with higher plasminogen $(r=0.17, p=0.02)$, antiplasmin $(r=0.22, p=0.0009)$, and protein $\mathrm{C}: \mathrm{Ag}(\mathrm{r}=0.53$, $\mathrm{p}<0.0001$ ).

\section{Discussion}

In the present study we found no associations between the extent of coronary atherosclerosis and an activation of the haemostatic system, either for activation of the platelet and coagulation system or for depression of the fibrinolytic system. These results may seem to be in conflict with recent experimental, angiographic, and histological studies of coronary thrombosis in unstable angina pectoris, acute myocardial infarction, and sudden cardiac death. ${ }^{1245}$ But none of our patients had an acute myocardial infarction and only a few of them had unstable angina. It is conceivable that myocardial ischaemia is a more important determinant of the activation of the haemostatic system than the extent of anatomical obstruction. ${ }^{518}$ Earlier studies did not demonstrate a relation between the extent of coronary atherosclerosis and concentrations of platelet

Table 1 Patient characteristics by angiographic category

\begin{tabular}{|c|c|c|c|c|c|c|}
\hline \multirow[b]{3}{*}{ Variable } & \multicolumn{5}{|c|}{ Angiographic category } & \multirow[b]{3}{*}{ Overall } \\
\hline & \multirow[b]{2}{*}{$\begin{array}{l}\text { No } \\
\text { changes }\end{array}$} & \multirow[b]{2}{*}{$\begin{array}{l}<50 \% \\
\text { stenosis }\end{array}$} & \multicolumn{3}{|c|}{ At least $50 \%$ stenosis in: } & \\
\hline & & & $\begin{array}{l}\text { One } \\
\text { vessel }\end{array}$ & $\begin{array}{l}\text { Two } \\
\text { vessels }\end{array}$ & $\begin{array}{l}\text { Three } \\
\text { vessels }\end{array}$ & \\
\hline $\begin{array}{l}\text { Number of patients } \\
\text { Number of men } \\
\text { Number with history of myocardial }\end{array}$ & $\begin{array}{l}63 \\
39(62)\end{array}$ & 14 (79) & $\begin{array}{l}49 \\
40(82)\end{array}$ & $\begin{array}{l}43 \\
37(86)\end{array}$ & $\begin{array}{l}56 \\
53(95)\end{array}$ & $225(80)$ \\
\hline $\begin{array}{l}\text { infarction } \\
\text { Number of current or past smokers } \\
\text { Number with akinesia or dyskinesia } \\
\text { Number with worsening of angina }{ }^{\star} \\
\text { Mean age (years) } \dagger\end{array}$ & $\begin{array}{l}12(19) \\
26(41) \\
2(3) \\
18(29) \\
51 \cdot 5\end{array}$ & $\begin{array}{l}2(14) \\
9(64) \\
0(0) \\
5(36) \\
51 \cdot 0\end{array}$ & $\begin{array}{l}24(49) \\
39(80) \\
18(37) \\
25(51) \\
52 \cdot 2\end{array}$ & $\begin{array}{l}30(70) \\
27(63) \\
21(49) \\
28(65) \\
52 \cdot 6\end{array}$ & $\begin{array}{l}38(68) \\
40(71) \\
21(38) \\
44(79) \\
54 \cdot 2\end{array}$ & $\begin{array}{l}106(47) \\
141(63) \\
62(28) \\
120(53) \\
52 \cdot 5(7 \cdot 0)\end{array}$ \\
\hline
\end{tabular}

$\star$ Percentages in brackets. $\uparrow S D$ in brackets. 
Table 2 Mean values of haematological and other variables by angiographic category

\begin{tabular}{|c|c|c|c|c|c|c|}
\hline \multirow[b]{3}{*}{ Variable } & \multicolumn{5}{|c|}{ Angiographic category } & \multirow[b]{3}{*}{ Overall (SD) } \\
\hline & \multirow[b]{2}{*}{$\begin{array}{l}\text { No } \\
\text { changes }\end{array}$} & \multirow[b]{2}{*}{$\begin{array}{c}<50 \% \\
\text { stenosis }\end{array}$} & \multicolumn{3}{|c|}{ At least $50 \%$ stenosis in : } & \\
\hline & & & $\begin{array}{l}\text { One } \\
\text { vessel }\end{array}$ & $\begin{array}{l}\text { Two } \\
\text { vessels }\end{array}$ & $\begin{array}{l}\text { Three } \\
\text { vessels }\end{array}$ & \\
\hline $\begin{array}{l}\text { PVC }(\%) \\
\text { Men } \\
\text { Women } \\
\text { WBC }\left(10^{6} / \mathrm{ml}\right)^{\star} \\
\text { WBPC }\left(10^{6} / \mathrm{ml}\right)^{\star} \\
\beta T G(\mathrm{ng} / \mathrm{ml})^{\star} \\
\text { PF4 }(\mathrm{ng} / \mathrm{ml})^{\star} \\
\text { vWF:Ag(\%) }\end{array}$ & $\begin{array}{c}46 \cdot 7 \\
41 \cdot 3 \\
5 \cdot 53 \\
245 \\
27 \cdot 8 \\
3 \cdot 85\end{array}$ & $\begin{array}{c}46 \cdot 8 \\
42 \cdot 7 \\
6 \cdot 81 \\
259 \\
31 \cdot 1 \\
4 \cdot 44\end{array}$ & $\begin{array}{c}46 \cdot 6 \\
43 \cdot 9 \\
6 \cdot 16 \\
226 \\
30 \cdot 8 \\
3.95\end{array}$ & $\begin{array}{c}47 \cdot 8 \\
43 \cdot 8 \\
6 \cdot 32 \\
215 \\
30 \cdot 4 \\
3 \cdot 50\end{array}$ & $\begin{array}{c}48 \cdot 2 \\
40 \cdot 7 \\
6 \cdot 48 \\
232 \\
30.9 \\
3.53\end{array}$ & 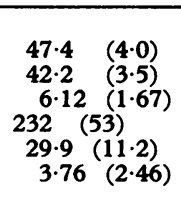 \\
\hline 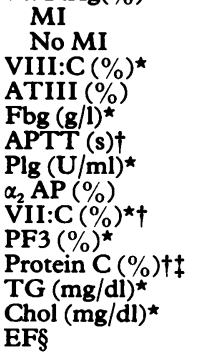 & $\begin{array}{c}126 \\
109 \\
159 \\
90 \\
3 \cdot 12 \\
43 \cdot 2 \\
4 \cdot 11 \\
102 \\
123 \\
124 \\
88 \\
143 \\
233 \\
76 \cdot 6 \%\end{array}$ & $\begin{array}{c}105 \\
76 \\
137 \\
85 \\
3 \cdot 31 \\
43 \cdot 8 \\
4 \cdot 10 \\
106 \\
111 \\
119 \\
86 \\
159 \\
244 \\
80 \cdot 1 \%\end{array}$ & $\begin{array}{c}130 \\
93 \\
155 \\
88 \\
3 \cdot 28 \\
43 \cdot 3 \\
4 \cdot 28 \\
98 \\
119 \\
121 \\
86 \\
173 \\
257 \\
66 \cdot 6 \%\end{array}$ & $\begin{array}{c}112 \\
103 \\
147 \\
84 \\
3 \cdot 20 \\
44 \cdot 0 \\
4 \cdot 16 \\
101 \\
118 \\
122 \\
84 \\
201 \\
247 \\
63 \cdot 0 \%\end{array}$ & $\begin{array}{c}128 \\
115 \\
153 \\
89 \\
3 \cdot 36 \\
43 \cdot 9 \\
4 \cdot 34 \\
100 \\
124 \\
121 \\
91 \\
192 \\
255 \\
63.8 \%\end{array}$ & $\begin{array}{c}123(55) \\
102(41) \\
153(76) \\
88(13) \\
3 \cdot 24(0 \cdot 71) \\
43 \cdot 6 \quad(4 \cdot 9) \\
4 \cdot 21(0 \cdot 75) \\
101(10) \\
121(24) \\
122(27) \\
87(14) \\
172(83) \\
247(48) \\
69 \cdot 4 \%(15 \cdot 2)\end{array}$ \\
\hline
\end{tabular}

factor $4^{61920}$ or fibrinopeptide A. ${ }^{621}$ The last study found that the extent of coronary artery disease and $\beta$ thromboglobulin concentrations were related in a group of 40 patients. ${ }^{21}$ Nichols $e t$ al, who studied 82 patients with ischaemic heart disease, only saw increased concentrations of platelet factor 4 and $\beta$ thromboglobulin in those patients in whom myocardial infarction had occurred (more than six months previously, other cases of myocardial infarction being excluded). ${ }^{6}$ The results of Nichols et al's study were interpreted as indicating that release of platelet factors in patients with ischaemic heart disease results from the reaction of platelets with the previously infarcted ventricular wall rather than with the arteriosclerotic coronary arteries.

In our study the inverse correlation between lower ejection fractions (which were generally associated with akinesia or dyskinesia of the left ventricle) and $\beta$ thromboglobulin concentrations, supports this interpretation. The strong positive correlation of antiplasmin and the ejection fraction and the negative correlation of fibrinogen with the ejection fraction that we found have yet to be explained.

We confirmed some other independent associations of haemostatic variables with established risk factors for coronary heart disease. Factor VII:C was strongly related to triglyceride concentration, ${ }^{322}$ and 3 plasminogen correlated directly with serum concentrations of triglycerides and cholesterol. ${ }^{23}$ Protein? $\mathrm{C}: \mathrm{Ag}$ was not raised in our patients (unlike other reports ${ }^{24}$ ), but it was independently associated with cholesterol. The close relations between factor VII and some components of the fibrinolytic system ${ }^{25}$ on 3 . the one hand and different indices of hyperlipoproteinemia on the other may well reflect anફ important pathogenetic factor in coronary hearto disease. In contrast, an association between cholesterol or triglyceride concentrations and plateleto aggregability could not be confirmed. ${ }^{26}$

The results obtained in the present study do not support the hypothesis that an activation of the $N$ haemostatic system associated with atherosclerotic coronary arteries is detectable in venous blood.0 Rather, they show that correlates of fibrin formation or platelet release are detectable when processes that are secondary to coronary atherosclerosis occur and? lead to vessel obstruction and ischaemic injury.

The cross sectional design of the present studyo means that the question of whether occlusive coro- $\mathbb{D}$ nary events are preceded by a long term activation of the haemostatic system remains unresolved. Theo results of our study do not conflict with previous 
epidemiological work ${ }^{3}$ that suggests that individual clotting factors influence the development of coronary heart disease.

This work was carried out within the framework of the Concerted Action on Thrombosis and Disabilities (ECAT) of the Commission of the European Communities as a pilot phase for a prospective study in angina pectoris patients. We thank the Landesversicherungsanstalt der Rheinprovinz, Düsseldorf, Federal Republic of Germany for financial support.

\section{References}

1 De Wood MA, Spores J, Notske R, et al. Prevalence of total coronary occlusion during the early hours of transmural myocardial infarction. $N$ Engl $J$ Med 1980;303:897-902.

2 Davies MJ, Thomas A. Thrombosis and acute coronary-artery lesions in sudden cardiac ischemic death. $N$ Engl J Med 1984;310:1137-40.

3 Meade TW, Brozovic M, Chakrabarti RR, et al. Haemostatic function and ischaemic heart disease: principal results of the Northwick Park Heart Study. Lancet 1986;ii:533-7.

4 Eisenberg PR, Sherman LA, Sherman K, Perez J, Sobel BE, Jaffe AS. Fibrinopeptide A: a marker of acute coronary thrombosis. Circulation 1985;71:912-8.

5 Gallino A, Haeberli A, Baur HR, Straub PW. Fibrin formation and platelet aggregation in patients with severe coronary artery disease: relationship with the degree of myocardial ischemia. Circulation 1985;72: 27-30.

6 Nichols AB, Owen J, Kaplan KL, Sciacca RR, Cannon PJ, Nossel HL. Fibrinopeptide A, platelet factor 4, and beta-thromboglobulin levels in coronary heart disease. Blood 1982;60:650-4.

7 Judkins MP. Percutaneous transfemoral selective coronary arteriography. Radiol Clin North Am 1968; 6:467-92.

8 Dodge HT, Sandler H, Ballew DW, Lord JD. The use of biplane angiocardiocardiography for the measurement of left ventricular volume in man. $\mathrm{Am}$ Heart J 1960;60:762-76.

9 Kennedy JW, Trenholme SE, Kasser IS. Left ventricular volume and mass from single-plane cineangiocardiogram. A comparison of anteroposterior and right anterior oblique methods. Am Heart J 1970; 80:343-52.

10 Herman MV, Heinle RA, Klein MD, Gorlin $\mathbf{R}$. Localized disorders in myocardial contraction. Asynergy and its role in congestive heart failure. $N$ Engl $J$
Med 1967;277:222-32.

11 Clauss A. Gerinnungsphysiologische Schnellmethode zur Bestimmung des Fibrinogens. Acta Haematol (Basel) 1957;17:237-46.

12 Kirchhof B, Balleisen L. Determination of platelet factor 3 by thrombin generation using a microcoagulation assay. Thromb Res 1982;27:303-10.

13 Ødegard OR. Evaluation of an amidolytic heparin cofactor assay method. Thromb Res 1975;7:351-60.

14 Teger-Nilsson AC, Friberger P, Gyzander E. Determination of a new rapid plasmin inhibitor in human blood by means of a plasmin specific tripeptide substrate. Scand J Clin Lab Invest 1977;37:403-9.

15 Knos M, Friberger P. Methods for plasminogen determination in human plasma and for streptokinase standardisation. Progress in Chemical Fibrinolysis and Thrombolysis 1979;4: 154-8.

16 Laurell CB. Quantitative estimation of protein by electrophoresis in agarose gel containing antibodies. Anal Biochem 1966;15:45-52.

17 Boyer C, Rothschild C, Wolf M, Amiral J, Meyer D, Larrieu MJ. A new method for the estimation of protein C by ELISA. Thromb Res 1984;36:579-89.

18 Sobel M, Salzman EW, Davies GC, et al. Circulating platelet products in unstable angina pectoris. Circulation 1981;63:300-6.

19 White GC, Marouf AA. Platelet factor 4 levels in patients with coronary artery disease. $\mathrm{J} \mathrm{Lab} \mathrm{Clin} \mathrm{Med}$ 1981;97:369-78.

20 Levine SP, Lindenfeld J, Ellis JB, Raymond NM, Krentz LS. Increased plasma concentrations of platelet factor 4 in coronary artery disease. Circulation 1981;64:626-32.

21 Van Hulsteijn H, Kolff J, Briet E, van der Laarse A, Bertina $\mathbf{R}$. Fibrinopeptide $A$ and beta-thromboglobulin in patients with angina pectoris and acute myocardial infarction. Am Heart $J$ 1984;107:39-45.

22 Dalaker K, Hjermann I, Prydz H. A novel form of factor VII in plasma from men at risk for cardiovascular disease. Br J Haematol 1985;61:315-22.

23 Wilhelmsen L, Svärdsudd K, Korsan-Bengtsen K, Larsson B, Welin L, Tibblin G. Fibrinogen as a risk factor for stroke and myocardial infarction. $N$ Engl $J$ Med 1984;311:501-5.

24 O'Connor NTJ, Broekmans AW, Bertina RM. Protein $\mathrm{C}$ values in coronary artery disease. $\mathrm{Br} \mathrm{Med} J$ 1984;289:1192.

25 Hamsten A, Wiman B, de Faire U, Blombäck $\mathbf{M}$. Increased plasma levels of a rapid inhibitor of tissue plasminogen activator in young survivors of myocardial infarction. $N$ Engl J Med 1985;313:1557-63.

26 Meade TW, Vickers MV, Thompson SG, Stirling Y, Haines AP, Miller GJ. Epidemiological characteristics of platelet aggregability. $\mathrm{Br} \mathrm{Med} J$ 1985;290: 428-32. 